\title{
Effect of Swimming Training on the Rectus Abdominis Muscle of rats: Morphological and Histochemical Aspects
}

\author{
Efecto de la Natación Sobre el Músculo Recto del Abdomen de la Rata: \\ Aspectos Morfológicos e Histoquímicos \\ "Maria José Alvarez Rosa; "*Vitalino Dal Pai; ${ }^{* * *}$ Hermann Bremer Neto; \\ ${ }^{* * * *}$ Reinaldo Azoubel \& *****Viviane Louise Andree Nouailhetas
}

ROSA, A. M. J.; DAL PAI, V.; BREMER NETO, H. B.; AZOUBEL, R. \& NOUAILHETAS, V. L. A. Effect of swimming training on the Rectus abdominis muscle of rats: Morphological and histochemical aspects. Int. J. Morphol., 25(3):631-638, 2007.

SUMMARY: We investigated the effect of swimming training in rats on morphological characteristics, hypertrophy levels and metabolic and contractile adaptations of different fiber types in rat the rectus abdominis muscle. Rats were randoverly assigned to one of three groups $(\mathrm{N}=5$ each): a) swimming training for $1 \mathrm{~h}$, twice a week $(2 \mathrm{x} / \mathrm{w}), \mathrm{b}) 1 \mathrm{~h}$ five times a week $(5 \mathrm{x} / \mathrm{w})$ for 9 consecutive weeks, or c) without any swimming training (Control). Body weight increased in $2 \mathrm{x} / \mathrm{w}$ rats and decreased in the $5 \mathrm{x} / \mathrm{w}$ ones. Muscle fiber diameters increased in both trained groups, with higher values in the $2 \mathrm{x} / \mathrm{w}$ group. Aerobic exercise increased slow oxidative (SO) + fastoxidative-glycolytic (FOG) fibers and decreased fast glycolytic (FG) fibers. In addition, SO fibers were increased and FOG + FG fibers were decreased in trained rats. Small and angulated atrophic fibers were also observed. These results corroborate that swimming exercise increases aerobic metabolism and thus oxidative and low contraction fibers. However, the used protocol induced, to a variable degree, changes in the muscle fiber morphology.

KEYWORDS: Aerobic exercise; Type fibers; Muscle.

\section{INTRODUCTION}

Mammal skeletal muscles have 3 types of fibers that are distributed in a mosaic pattern and have specific morphological, contractile and metabolic characteristics. Type I fibers, called slow oxidative (SO), have slow contraction velocity, oxidative metabolism, large amounts of myoglobin and adaptation to endurance activities; oxidative phosphorylation of fatty acids is their main energy source. Type IIA fibers, the fast-oxidative-glycolytic (FOG), have high contraction velocity, oxidative-glycolytic metabolism and high resistance to fatigue. Type IIB fibers, the fast glycolytic metabolism (FG), show fast contraction, glycolytic metabolism and low resistance to fatigue (Dubowitz \& Brooke, 1972; Petter et al., 1972; Booth \& Baldwin, 1996).

The different muscle fibers are recruited as exercise intensity is increased. Therefore, cytological characteristics of the fiber types should be considered in the selection of an exercise modality so that a better muscle performance is achieved (Shell, 2002).

Abbrecht et al. (1991) have shown that the activation of respiratory muscles during physical endurance activities, such as running, cycling, swimming and rowing, promotes a high adaptation of fiber types. In fact, respiratory exercises combined with water exercises improved gas exchange in patients suffering from chronic obstructive pulmonary disease. Despite these data, studies on the effects of physical endurance exercise on the adaptation of the fiber types of different muscles are still scarce, particularly with regard to respiratory muscles. Thus, this study investigated the morphological traits, hypertrophy levels and the metabolic and contractile adaptations of different fiber types in the rectus abdominis muscle of rats. This respiratory muscle is important for expiration and is recruited actively during swimming effort.

Department of Physiotherapy - UNOESTE, Presidente Prudente, SP, Brasil.

** Department of Histology - UNOESTE, Presidente Prudente, SP, Brasil.

*** Department of Biophisics - UNOESTE, Presidente Prudente, SP, Brasil.

***** Department de Pos-Graduation -FAMERP, SP, Brasil.

****** Department of Biophisics - UNIFESP, São Paulo, SP, Brasil. 


\section{MATERIAL AND METHOD}

This research was previously approved by the Ethical Committee of the Universidade do Oeste Paulista (UNOESTE - Presidente Prudente, SP, Brazil). Fifteen adult male Wistar rats (body weight $=380 \pm 12 \mathrm{~g}$ ), obtained from the animal facilities of the Universidade Estadual Paulista (UNESP - Campus at Botucatu-SP) and held in the Stress Laboratory (UNESP - Campus Presidente Prudente-SP) under $12 \mathrm{~h}: 12 \mathrm{~h}$ light: dark period, were randomly assigned to one of three experimental groups $(\mathrm{N}=5$ each). All the groups underwent a progressive period of adaptation to the aquatic environment, $1 \mathrm{~h} /$ day for 5 days, in a $50 \mathrm{~cm}$ depth tank $(100 \times 50 \times 60 \mathrm{~cm})$. Water temperature was $30^{\circ} \pm 1^{\circ} \mathrm{C}$. All the groups receiving feeding and water ad libitum. The rats from the trained groups were subjected to swimming training twice $(2 \mathrm{x} / \mathrm{w}$; body weight $=394 \pm$ $13 \mathrm{~g})$ or 5 times a week $(5 \mathrm{x} / \mathrm{w}$; body weight $=398 \pm 12 \mathrm{~g})$ for 9 consecutive weeks and five rats (body weight $=385$ $\pm 9 \mathrm{~g}$ ) from the control group remained sedentary. The training sesion continued of $60 \mathrm{~min}$ enforced swimming. Rats from Group 2x/w were trained on Monday and Wednesday, while rats from group $5 \mathrm{x} / \mathrm{w}$ were trained from Monday to Friday. After the training period ( 9 weeks), all animals were weighed and sacrificed by intraperitoneal injection of thiopental at $20 \mathrm{mg} / 100 \mathrm{~g}$ body weight, the concentration for muscle analyses (Pyshikin \& Baulin, 1969).

Two segments ( $1.0 \mathrm{~cm}$ length and $0.6 \mathrm{~cm}$ diameter) of the right median portion of the rectus abdominis muscle were isolated. These tissue samples were immersed in $\mathrm{N}$ Hexane at $-70{ }^{\circ} \mathrm{C}$, for $2 \mathrm{~min}$. A series of histological sections $(8 \mu \mathrm{m})$ were obtained with a cryostat microtome [(model - Cryocut $1850 /$ mark - Reichert - Young $\left.\left(-20^{\circ} \mathrm{C}\right)\right]$ and stained using haematoxylin and eosin (HE) (McMannus \& Mowry, 1964). Transversal sections of 100 fibers from each animal were analyzed by with an optical microscope (model YS2-T - JAPAN) coupled to a camera system for image capture (model CV 430 PDC-12-VDC800 MA, made in Japan) connected to an IBM personal computer $300 \mathrm{GL}$; and analyzed with the software IMAGE LAB 2000, developed by the Universidade de São Paulo (USP - São Paulo - Brazil). The mean diameter of the fibers of each animal was measured and presented as frequency of $10 \mu \mathrm{m}$ intervals each.

The metabolism of the muscle was evaluated by determinig the frequencies of oxidative $(\mathrm{SO}+\mathrm{FOG})$ and glycolitic fibers (FG) in tissue sections after treatment with for nicotinamide dinucleotide tetrazolium reductase method (NADH-TR) (Dubowitz et al., 1985). A total at
100 fibers were sampled in 12 microscopic fields (ocular $8 \mathrm{x}$ and objective 40x) for each animal. The contraction velocity of the muscle was evaluated based on frequency of slow (SO) and fast (FOG+FG) contraction fibers in the histological preparations submitted to myofibrillar adenosine triphosphatase method (m-ATPase) after acid $(\mathrm{pH}$ 4.6) and alkalin $(\mathrm{pH}$ 10.4) pre-incubations was performed (Dubowitz et al.). The description, classification and nomenclature of fibers were done according to Petter et al. (1972): slow-twitch oxidative (SO), fast-twitch oxydative-glycolitic (FOG); fast-twitch Glycolitic (FG).

Data on body weight $(\mathrm{g})$, fiber diameter $(\mu \mathrm{m})$, frequency of oxidative and glycolytic fibers, frequency of slow and fast contraction fibers at $\mathrm{pH} 4.6$ and 10.4 and fiber diameter at $10 \mu \mathrm{m}$ intervals were subjected to variance analysis followed by Student t-test (Berquó et al., 1981). Statistical significance was considered at $p$ values lower than 0.05 level.

\section{RESULTS}

The mean diameter of muscle fibers from $2 \mathrm{x} / \mathrm{w}$ group was higher than that in $5 \mathrm{x} / \mathrm{w}$ rats (Table I). And both animal groups have the fiber diameter higher than fiber diameter low control group (Fig. 1). As indicated by the oxidative metabolism ( $\mathrm{SO}+\mathrm{FOG})$, the mean frequency of fibers from the rectus abdominis muscle was not different between $2 x / w$ and $5 x / w$ rats, and this frequency was lower in the control rats compared to both of the trained groups. The frequency of FG fibers was similar between $2 x / w$ and $5 x / w$ rats, and the mean frequency of fibers in the control rats was lower than in both the trained groups (Fig. 2). The mean frequency of SO fibers from the rectus abdominis muscle in acid medium ( $\mathrm{pH}$ 4.6) was lower in the control group compared to the other groups and lower in $2 \mathrm{x} / \mathrm{w}$ compared to the $5 \mathrm{x} / \mathrm{w}$ group. The mean frequency of fast contraction fibers $(F O G+F G)$ from the rectus abdominis muscle in acid medium ( $\mathrm{pH} 4.6$ ), was lower in $5 \mathrm{x} / \mathrm{w}$ group, compared to the other groups and lower in $2 \mathrm{x} / \mathrm{w}$, compared to the control group. The mean frequency of SO fibers from the rectus abdominis muscle in alkaline medium ( $\mathrm{pH}$ 10.4) was not different between $2 \mathrm{x} / \mathrm{w}$ and $5 \mathrm{x} / \mathrm{w}$ groups, but in both of these groups SO fibers were more frequent than in the control group. The mean frequency of fast contraction fibers $(\mathrm{FOG}+\mathrm{FG})$ from the rectus abdominis muscle in alkaline medium $(\mathrm{pH}$ 10.4) was not different between $2 x / w$ and $5 x / w$ groups, but both of these groups had lower frequencies of fast contraction fibers compared to the control group (Fig. 3). 
Table 1. Percentage of rats according to class of fiber diameter and treatments.

\begin{tabular}{cccc}
\hline Fiber diameters $(\mu \mathrm{m})$ & Control & $2 \mathrm{x} / \mathrm{w}$ & $5 \mathrm{x} / \mathrm{w}$ \\
\hline $0-10$ & $0.0^{\mathrm{a}}$ & $0.0^{\mathrm{a}}$ & $0.0^{\mathrm{a}}$ \\
$11-20$ & $4.5^{\mathrm{a}}$ & $4.7^{\mathrm{a}}$ & $2.2^{\mathrm{a}}$ \\
$21-30$ & $14.7^{\mathrm{b}}$ & $12.5^{\mathrm{ab}}$ & $10.5^{\mathrm{a}}$ \\
$31-40$ & $14.0^{\mathrm{b}}$ & $13.5^{\mathrm{ab}}$ & $11.7^{\mathrm{a}}$ \\
$41-50$ & $19.5^{\mathrm{b}}$ & $17.5^{\mathrm{b}}$ & $11.0^{\mathrm{a}}$ \\
$51-60$ & $21.0^{\mathrm{b}}$ & $16.5^{\mathrm{a}}$ & $16.5^{\mathrm{a}}$ \\
$61-70$ & $15.0^{\mathrm{a}}$ & $15.5^{\mathrm{a}}$ & $17.5^{\mathrm{a}}$ \\
$71-80$ & $7.7^{\mathrm{a}}$ & $8.7^{\mathrm{a}}$ & $13.5^{\mathrm{b}}$ \\
$81-90$ & $2.7^{\mathrm{a}}$ & $7.5^{\mathrm{b}}$ & $10.5^{\mathrm{c}}$ \\
$91-100$ & $1.5^{\mathrm{a}}$ & $2.0^{\mathrm{ab}}$ & $4.5^{\mathrm{b}}$ \\
$101-110$ & $0.2^{\mathrm{a}}$ & $0.5^{\mathrm{a}}$ & $1.75^{\mathrm{a}}$ \\
$111-120$ & $0.0^{\mathrm{a}}$ & $0.2^{\mathrm{a}}$ & $0.5^{\mathrm{a}}$ \\
$121-130$ & $0.0^{\mathrm{a}}$ & $0.0^{\mathrm{a}}$ & $0.25^{\mathrm{a}}$ \\
\hline
\end{tabular}

Control rats (no swimming training) and rats forced to swim 2 or 5 times per week $(2 \mathrm{x} / \mathrm{w}$ or $5 \mathrm{x} / \mathrm{w}$, respectively).

Different letters superscripts in each line indicate statistical difference among the groups (Student t-test, $\mathrm{p}<0.05$ ).

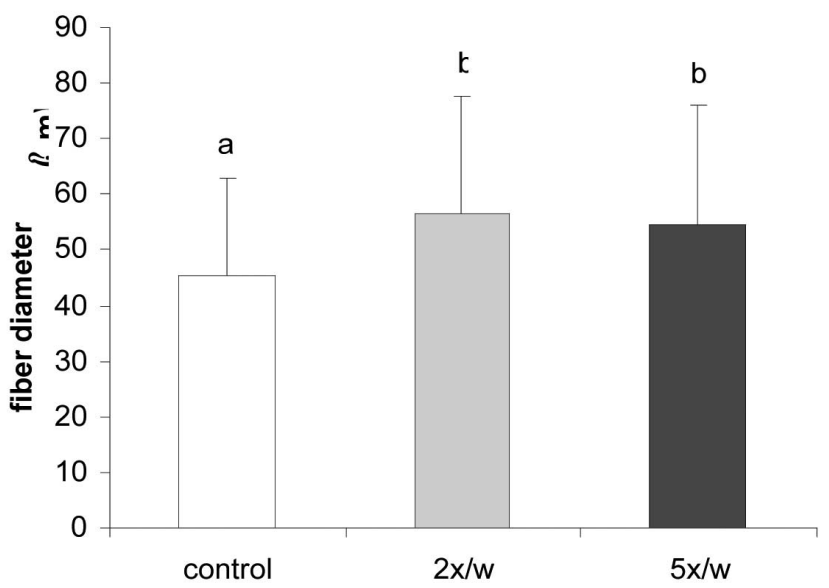

Fig. 1. Mean fiber diameter $(+\mathrm{sd})$ of control rats and rats subjected to swimming training for $1 \mathrm{~h}$ twice a week $(2 \mathrm{x} / \mathrm{w})$ and $1 \mathrm{~h}$ five times a week $(5 \mathrm{x} / \mathrm{w})$ for 9 weeks. Different letters indicate statistical differences among means (ANOVA followed by Student t-test, $\mathrm{p}<0.05)$.

In the control group, the frequency of fibers measuring from 0 to $60 \mu \mathrm{m}$ diameter (measured at $10 \mu \mathrm{m}$ intervals) increased and then decreased up to diameter 130 $\mu \mathrm{m}$ (Table I). In group $2 \mathrm{x} / \mathrm{w}$ the frequency of fibers with diameter from 0 to $50 \mu \mathrm{m}$ increased and then decreased up to $130 \mu \mathrm{m}$ (Table I). In the $5 \mathrm{x} / \mathrm{w}$ group the percentage of fibers from 0 to $70 \mu \mathrm{m}$ increased and after decreased up to $130 \mu \mathrm{m}$ (Fig. 4 and Table I).

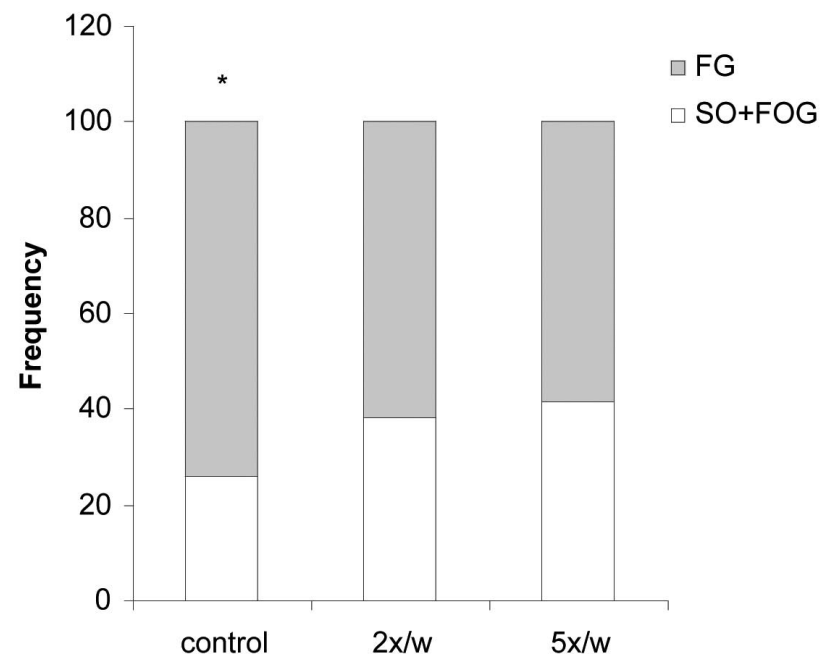

Fig. 2. Percentage of oxidative $(\mathrm{SO}+\mathrm{FOG})$ or glycolytic $(\mathrm{FG})$ fibers of the rectus abdominis muscle fibers of control rats and rats subjected to swimming training for $1 \mathrm{~h}$ twice a week $(2 \mathrm{x} / \mathrm{w})$ and 1 $\mathrm{h}$ five times a week $(5 \mathrm{x} / \mathrm{w})$ for 9 weeks. $*$ indicates statistical difference compared with the other two groups (ANOVA followed by Student t-test, $\mathrm{p}<0.05$ ).

Morphological analysis of the rectus abdominis muscle of the rats under HE staining revealed that control rats had polygonal fibers of different diameters, abundant acidophilic cytoplasm, one or more nuclei at peripherical position; connective tissue surrounded the fibers (Fig. 4a). Based on NADH-TR reactivity, three fiber types (SO, FOG and FG) were identified in a mosaic distribution. The SO fibers are smaller and more intensively stained; those with mild reactivity are the FOG fibers, and those with pale staining are the FG (Fig. 4b). Moreover, m-ATPase reaction after acid preincubation revealed these three fiber types. Accordingly, $\mathrm{SO}$ was the smallest and most intensely stained, FOG were intermediates, and FG the least reactive ones (Fig. $4 \mathrm{c})$. After preincubation in $\mathrm{pH} 10.4$ solution, the fibers had activity reversed (Fig. 4d).

In the $2 x / w$ group, the rectus abdominis muscle had some fibers with severe hypertrophy and next to small and intermediate diameter fibers. These fibers had a more acidophilic cytoplasm compared to the control group and elongated cytoplasm with angular contour (Fig. 5 a). The NADH-TR reaction was strong in the small SO fibers, especially the angular atrophic ones. The FG hypertrophic cells had weak reactivity, whereas those with intermediate diameter (FOG) had mild reactivity (Fig. 5 b). In the mATPase reaction at $\mathrm{pH} 4.6$ most of the fibers were FG and had a large diameter and weak reactivity; FOG fibers had mild reactivity and SO fibers a strong reactivity and lower diameter (Fig. 5 c). At pH 10.4, the smaller fibers (SO) reacted weakly, while the largest ones (FOG and FG) ranged from mild to strong reactivities (Fig. $5 \mathrm{~d}$ ). 


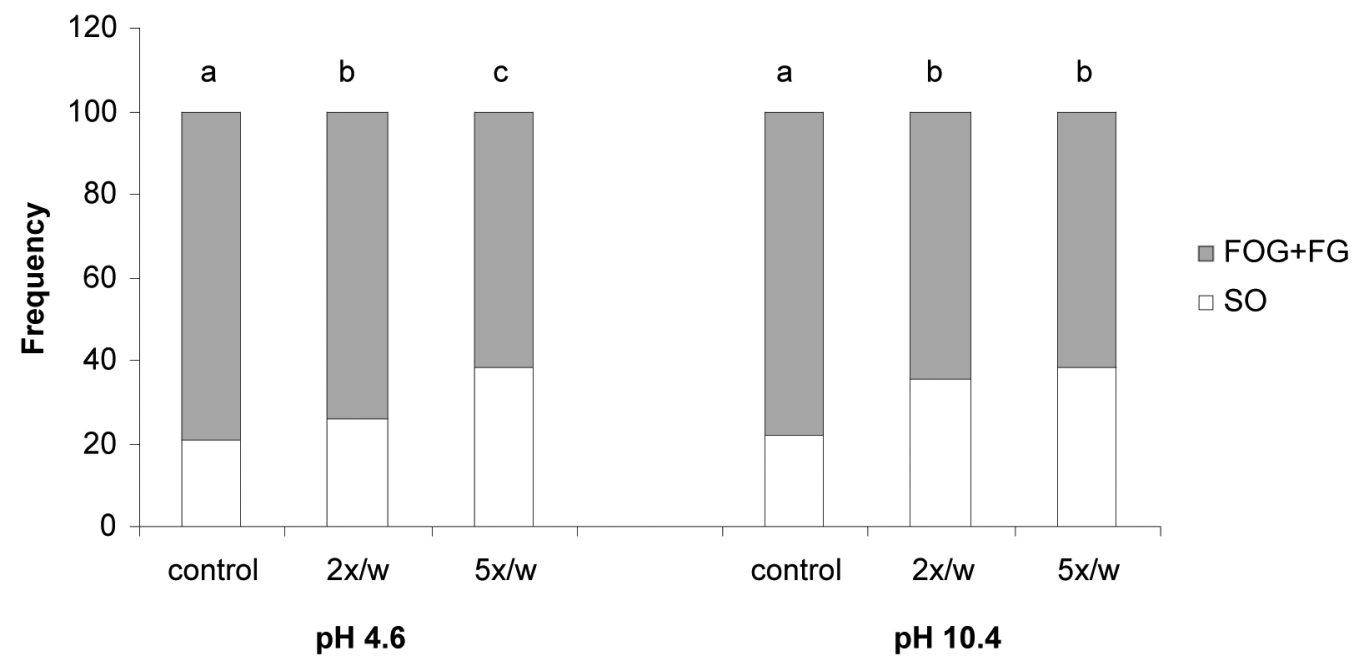

Fig. 3. Percentage of slow (SO) or fast $(\mathrm{FOG}+\mathrm{FG})$ fibers of the rectus abdominis muscle fibers in control rats and rats subjected to swimming training for $1 \mathrm{~h}$ twice a week $(2 \mathrm{x} / \mathrm{w})$ and $1 \mathrm{~h}$ five times a week $(5 \mathrm{x} / \mathrm{w})$ for 9 weeks. Fibers were preincubated in acid $(\mathrm{pH} 4.6)$ or alkaline $(\mathrm{pH} 10.4)$ medium. Different letters indicate statistical differences among groups (ANOVA followed by Student t-test, $\mathrm{p}<0.05$ ).
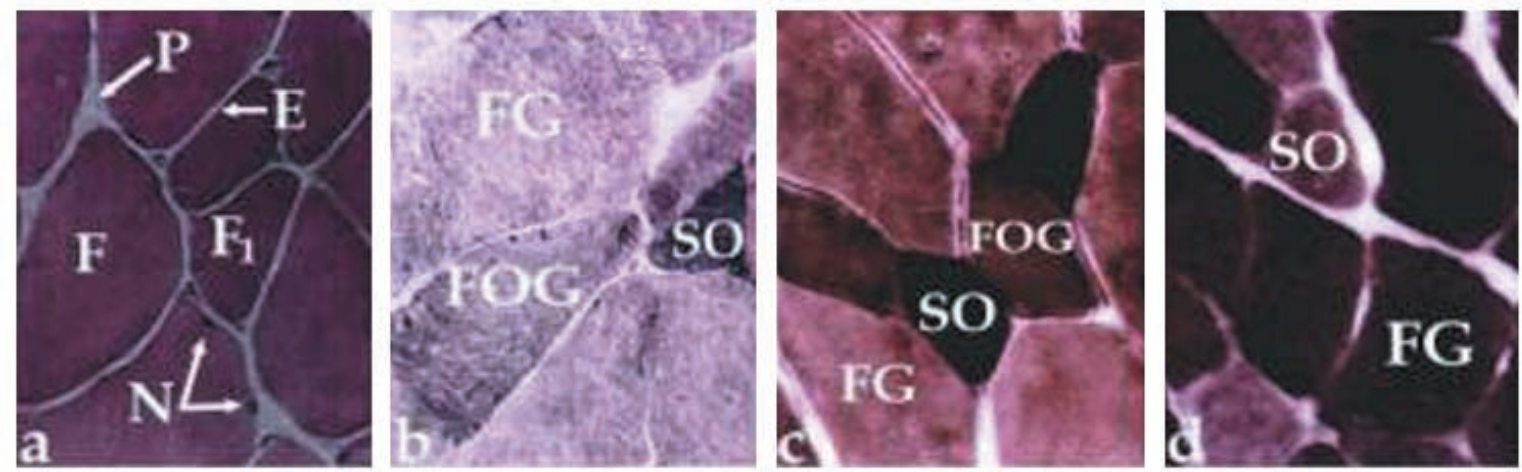

Fig. 4. Transversal section of the rectus abdominis muscle of control rats. a) fibers with different diameters (F), peripherical nucleus ( $\mathrm{N}$ and arrow), perimysium ( $\mathrm{P}$ and arrow) and endomysium (E and arrow) (HE-400x). b) SO, FOG and FG fibers identified by NADH-TR reaction $(400 \mathrm{x})$. c)- SO, FOG and FG fibers identified by m-ATPase reaction at pH $4.6(400 \mathrm{x})$. d) fibers of slow ( $\mathrm{SO}$ ) and fast (FG) contraction indetified by the m-ATPase reaction at $\mathrm{pH} 10.4$ (400x).
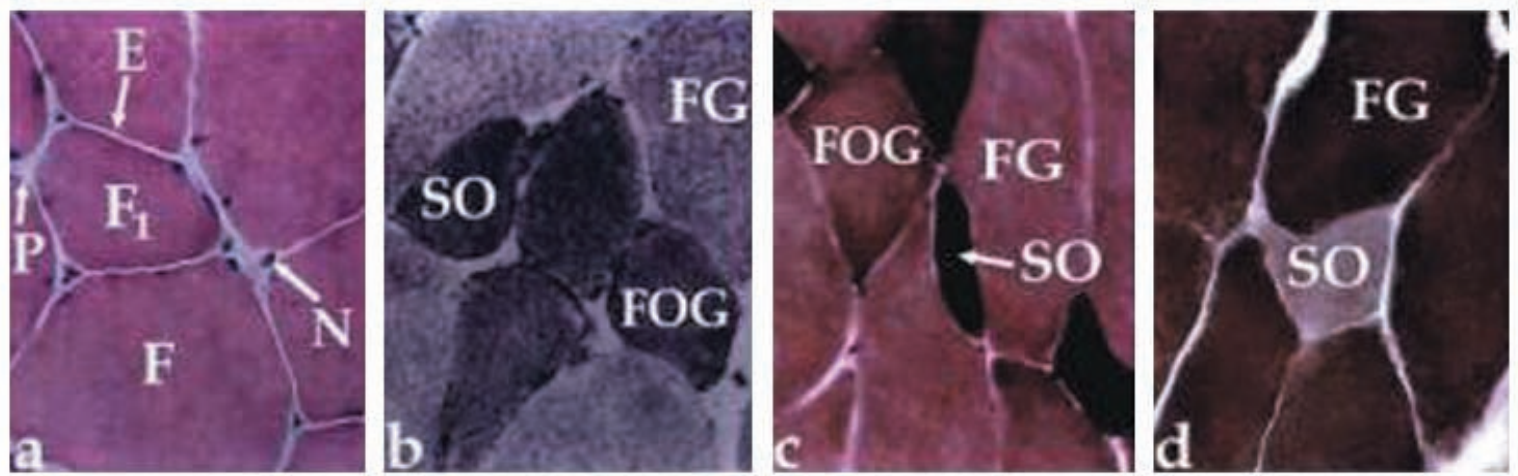

Fig. 5. Transversal section of the rectus abdominis muscle of rats subjected to $2 x / w$ swimming training. a) hypertrophic fibers $(\mathrm{F})$ angular atrophic fibers (F1) peripherical nucleus ( $\mathrm{N}$ and arrow), perimysium ( $\mathrm{P}$ and arrow) and endomysium (E and arrow) (HE-400x). b) SO, FOG and FG hypertrophic fibers identified by NADH-TR reaction (400 x). c) SO (1), FOG (2) and FG (3) fibers identified by m-ATPase reaction at $\mathrm{pH} 4.6(400 \mathrm{x})$. d) fibers of slow (SO) and fast (FG) contraction indetified by the m-ATPase reaction at $\mathrm{pH} 10.4$ (400x). 

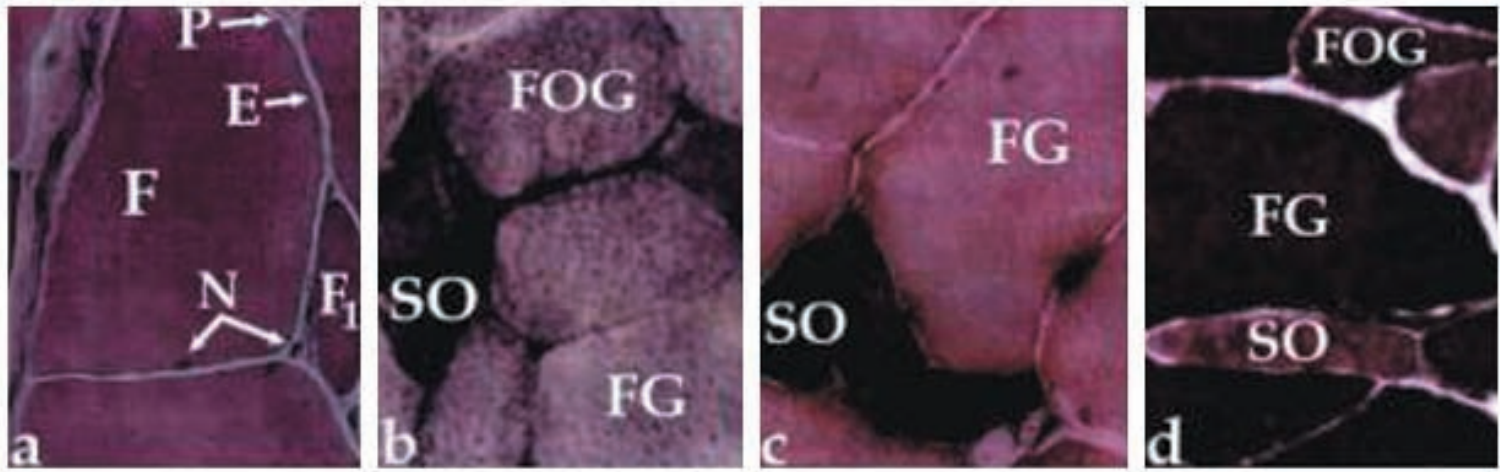

Fig. 6. Transversal section of the rectus abdominis muscle of rats subjected to $5 \mathrm{x} / \mathrm{w}$ swimming training. a) hypertrophic round fibers $(\mathrm{F})$ atrophic fibers $(\mathrm{F})$ peripherical nucleus $(\mathrm{N}$ and arrow), perimysium ( $\mathrm{P}$ and arrow) and endomysium (E and arrow) (HE-400x). b) SO, FOG and FG fibers identified by NADH-TR reaction (400 x). c) atrophic, slow contraction fibers ( $\mathrm{SO}$ ) and hypertrophic, fast contraction fibers (FG) identified by m-ATPase reaction at $\mathrm{pH} 4.6$ (400 x). d) atrophic, slow contraction fibers ( $\mathrm{SO}$ ), atrophic, fast contraction fibers (FOG) and hypertrophic, fast contraction fibers (FG) identified by $\mathrm{m}$-ATPase reaction at $\mathrm{pH} 10.4(400 \mathrm{x})$.

The HE stained sections obtained from $5 \mathrm{x} / \mathrm{w}$ rats, also showed hypertrophic fibers and different contour. There were observed small fibers and larger elongated ones, and atrophic acidophilic cytoplasm (Fig. 6 a). The NADH-TR reaction was strong for the small SO fibers, which were more heterogeneously distributed in comparison to the other groups. This reaction was mild in the FOG fibers and weak in the FG ones (Fig. 6 b). The m-ATPase reaction at $\mathrm{pH} 4.6$ revealed small SO fibers with strong reactivity, intermediate FOG fibers with mild reactivity and large FG fibers with weak reactivity (Fig. $6 \mathrm{c}$ ). When fibers were preincubated in alkaline medium ( $\mathrm{pH}$ 10.4), the fibers with low diameter (SO and FOG) had weak to mild reactivity, while the larger FG fibers with triangular contour had strong reactivity (Fig. 6 d).

\section{DISCUSSION}

The variation in the different modalities of endurance exercises has a variable effect on the body weight of rats. In an 8-week protocol, thin and fat rats reduced body weight (Mole \& Stern, 1982); in another protocol, rats subjected to endurance exercises decreased body weight from $449 \mathrm{~g}$ to 371g (Tamaki, 1987).

Eight youths subjected to bicycle exercise 2-h a day for 3 weeks did not change body weight after exercise, even if receiving carbohydrate $(150 \mathrm{~g})$ during this activity (Bock et al., 2006).

In the present study, the exercises increased body weight in all the treatments. At the end of the study, weight gain was higher in rats from $2 \mathrm{x} / \mathrm{w}$ compared to $5 \mathrm{x} / \mathrm{w}$. Also, these groups gained more weight than the control group.
The occurrence of more amorphous aggregates of formazan was a consequence of the increase in oxidative metabolic activity and mitochondria grouping. In this study the fibers were isolated and distributed among other fibers, as observed in denerved fibers (Dubowitz et al.). The atrophic aspect of these fibers appears to occur from lack of contact with the nerve endings of the myoneural junction. Hypertrophic fibers were observed in 2x/w and especially in $5 \mathrm{x} / \mathrm{w}$ rats. Other fibers showed a normal aspect, and some were atrophic. The exercise protocol promoted higher hypertrophy of FG fibers. In fact, the structure of these fibers is compatible with the hypertrophic process (Petter et al.). Comparing the groups studied, hypertrophy was more pronounced in the $2 \mathrm{x} / \mathrm{w}$ group.

A study about the effects of chronic stimulation on the weight of fetuses and associated structures during pregnancy (60-63 days), revealed discrete changes in the frequency of both SO and FOG fibers and hypertrophy of FOG fibers (Carvalho, 2003). In the present study, the muscle studied had high percentage of FG fibers, and both the effects of prolonged exercise on the modulation of fiber types and hypertrophy of FG fibers were more pronounced.

A study associating age and modification in fiber types in swine aged 6-18 months revealed that slow fibers decreased in both rectus abdominis and vastus medialis muscles, and slow fibers were more numerous in the vastus medialis muscle. Both the age and muscle function are modifying factors of the fiber type (Cappelo et al., 2000). In addition, age is characterized by a lower level of myocytes and reduction in the transversal area of the fibers, especially type II fibers (Song et al., 2006).

In the rats that trained at a higher frequency $(5 \mathrm{x} / \mathrm{w})$, 
the endurance exercise promoted a slighter increase of FG fibers than both control and $2 \mathrm{x} / \mathrm{w}$ groups. This observation confirms that frequency of endurance exercise is highly correlated with hypertrophy level in the muscle fibers. According to previous studies, this modality of exercise induces modulation of fiber type by converting FOG fibers into both SO and FG fibers (Dubowitz \& Brooke, 1972).

Trappe et al. (2000) studied male, healthy humans subjected to swimming training at $200 \mathrm{~m} /$ day, 6 days $/ \mathrm{w}$ for 5 months and found that the diameter of type I fiber was not affected, but type IIA fibers of the rectus abdominis muscle increased $11 \%$. According to this author, the increases in diameter, strength and aerobic capacity of type IIA fibers improve oxidative capacity of the muscle. The diameter of type IIA fibers increased $11 \%$ and $9 \%$, respectively, in groups $2 \mathrm{x} / \mathrm{w}$ and $5 \mathrm{x} / \mathrm{w}$. These results corroborate the findings of Mitchell et al. (2004), who observed a $20 \%$ increase in the oxidative fibers and a reduction in glycolitic fibers in the vastus lateralis muscle of rats in female Sprague-Dawley, which performed no exercise training: low intensity $(8 \mathrm{~m} / \mathrm{min})$ treadmill running; or high-intensity $(28 \mathrm{~m} / \mathrm{min})$ treadmill running.

Humans undergoing bicycle training 2-h a day for 3 weeks, had IIA fibers increased and type I fiber decreased in the vastus lateralis muscle (Bock et al., 2006). Men under 8week progressive endurance training also had IIA fibers increased in the vastus lateralis muscle from the second week of training onward (Woolstenhume et al., 2006).

These results indicate that even low training frequency of endurance exercises increases the diameter of oxidative fibers and reduces glycolytic fibers.

Controversially, the rectus abdominis muscle of dogs is essentially red and contains $98.4 \%$ oxidative fibers and $1.6 \%$ glycolytic fibers (Carvalho).

Ito (1998) showed that fiber composition of the abdominal muscles (internal and external oblique muscles, transversus and rectus abdominis) of Japanese monkeys was similar: $26 \%$ type I fiber, $22 \%$ type IIA fibers and 52\% type IIB fibers. Augusto et al. (2004) obtained similar results in C57BL6J rats. In the present study, the rectus abdominis muscle of rats had $26 \%$ oxidative fibers and $74 \%$ glycolytic fibers, evidencing similarity in the percentages of these two animals.

Although the FG-fiber hypertrophy was higher in $2 \mathrm{x} / \mathrm{w}$ compared to $5 \mathrm{x} / \mathrm{w}$ rats, the frequencies of aerobic fibers $(\mathrm{SO}+$ FOG ) were higher as well. These alterations were similar to $5 \mathrm{x} / \mathrm{w}$. Mcardle (2002) found an improvement in the oxidative capacity of the fibers studying the same training session used in the present study. According to this author, training frequencies under $2 x / w$ do not change significantly either the metabolic capability of the fibers or body composition.

In rats subjected to running exercise for 15 weeks, the frequency of type I and type IIB fibers of the rectus abdominis muscle were increased and decreased, respectively. Thus, similarly to running, swimming is an aerobic exercise that increases oxidative and decreases glycolytic fibers (Hijikata et al., 1992). Humans subjected to a 15 -week training on a cycle ergometer for 15-90s at 4-5x/w had type I fibers increased and type IIB fibers decreased, both in the vastus lateralis muscle; fibers IIA were not changed (Simoneau et al., 1985). Contraction and relaxation exercises increase type I fibers and decreases type II fibers in the contractile properties of the diaphragm of humans (Moore et al., 2006). Korhonen et al. (2006) reported that humans subjected to isometric exercises had type I fibers increased and type II fibers decreased in the vastus lateralis muscle.

The present study showed that both $2 x / w$ and $5 x / w$ rats had an increase of $45 \%$ and $55 \%$ in the oxidative metabolism and an increase of $13 \%$ and $15 \%$ in the glycolytic metabolism, respectively. This result evidences that even in lighter training programs, oxidative and glycolytic metabolisms of rectus abdominis muscle are changed.

Powers et al. (1992) showed that rats subjected to treadmill training $\left(6^{\circ}\right.$ inclination 4-5x/week, $60 \mathrm{~min} /$ day for 10 weeks) increased by $14 \%$ and $17 \%$, respectively, type I and IIA fibers from diaphragm, while type II fibers were not altered. Another study on endurance exercise in rats subjected to training at 1h/day, 6 days/week for 9 weeks, augmented the oxidative activity $26 \%$ in the rectus abdominis muscle of rats (Uribe et al., 1992). Similarly to those studies, the present study also reports increase in fiber metabolism from the rectus abdominis muscle.

Grinton et al. (1992) showed that endurance training (45 min daily running for 12 weeks) in Sprague-Dawley rats increased by $13 \%$ the oxidative activity in external oblique and rectus abdominis muscles and $44 \%$ in the plantar flexor muscles. This indicates that endurance training may increase oxidative metabolism in both respiratory and locomotor muscles. In the same way, endurance training in healthy humans improves resistance of rectus abdominis, internal and external obliques and abdominis tranversus muscles (Shell, 2002).

The present study also showed the effects of endurance exercise on modulation of contractile capacities of the fiber types. The control rats had $20.8 \%$ slow contraction fibers (SO) and $79.2 \%$ fast contraction fibers (FOG + FG). Saad et 
al. (2002) reports that control rats had $15.5 \%$ slow contraction fibers (SO) and $84.4 \%$ fast contraction fibers (FOG+FG). This difference is probably because each study sampled a different portion of the muscle.

Powers et al. (1997) showed that rats training on a treadmill at $8^{\circ}$ inclination, $1 \mathrm{~h} /$ day, 5days/week for 6 weeks, increased the slow contraction fibers by $20-56 \%$, as well as the vascularization level in soleus and plantar muscles.

Finally, morphological changes in muscle fibers were found, indicating that swimming exercise modulated the fiber types by increasing participation of oxidative and slow contraction fibers.

ROSA, A. M. J.; DAL PAI, V.; BREMER NETO, H. B.; AZOUBEL, R. \& NOUAILHETAS, V. L. A. Efecto de la natación sobre el músculo recto del abdomen de la rata: Aspectos morfológicos e histoquímicos. Int. J. Morphol., 25(3):631-638, 2007.

RESUMEN: Se estudió el efecto de la natación en las características morfológicas, niveles de hipertrofia y las adaptaciones metabólicas y contráctiles de diferentes tipos de fibras en el músculo recto del abdomen de ratas. Las ratas fueron asignadas en tres grupos ( $\mathrm{N}=5$ cada uno): a) natación por 1 hora dos veces a la semana $(2 \mathrm{x} / \mathrm{s})$, b) 1 hora, cinco veces por semana $(5 \mathrm{x} / \mathrm{s})$ por nueve semanas consecutivas y c) sin natación (control). El peso corporal se incrementó en las ratas 2x/s y disminuyó en $5 \mathrm{x} / \mathrm{s}$. El diámetro de las fibras musculares aumentó en ambos grupos entrenados, con mayores valores en las ratas 2x/s. El ejercicio aeróbico incrementó las fibras de oxidación lenta $(\mathrm{OL})$ + las fibras de glicólisis oxidativa rápida (GOR) y disminuyeron las fibras de glicólisis rápida (GR). Además, las fibras OL aumentaron y las fibras GOR y GR disminuyeron en las ratas entrenadas. Se observó una pequeña atrofia y deshidratación de las fibras. Estos resultados corroboran que la práctica de la natación incrementa el metabolismo aeróbico, las fibras de contracción lenta y la oxidación. Sin embargo, el protocolo utilizado induce cambios en grado variable en la morfología de las fibras musculares.

PALABRAS CLAVE: Ejercicio aeróbico; Tipo de fibras; Músculo.

\section{REFERENCES}

Abbrecht, P.; Rajagopal, Kyle K. Expiratory muscle recruitment during inspiratory flow-resistance loading and exercise. Am. Ver. Resp. Dis., 144:113-20, 1991.

Augusto, A.; Padovani, C. R. \& Campos, G. E. R. Skeletal muscle fiber types in C57bl6J mice. Braz. J. Morphol. Sci. 21(2):89-94, 2004.

Bock, D. K.; Derave, W.; Ramaekers, M.; Richter, E. A. \& Hespel, P. J. Fibre type specific muscle glycogen sparing due to carbohydrate intake before and during exercise. J. Appl. Physiol., 54:142-9, 2006.

Berquó, E. S.; Souza, J. M. P.; Gotlier, S. L. D. \& Souza, J. F. P. Bioestatística. São Paulo, Pedagógica e Universitária (EDUSP), 1981. 350p.

Booth, F. W. \& Baldwin, K. M. Muscle plasticity: energy demanding and supply processes. In: Peachey, L. D.; Adrian, R. H. \& Geiger, S. R. Edit. Handbook of physiology, section 12. Williams \& Wilkins, Baltimore, 1996. pp. 1075-123.

Cappello, F.; Peri, G.; Palma, A.; Bacchieri, F.; Balsano, G.; Pomara, C.; Zummo, G. \& Farina, F. Age-related changes in skeletal muscle fiber composition in two swine muscles. Ital. J. Anat. Embryol., 105(2): 91-96, 2000.
Carvalho, G. C. Morphology, metabolism, and contractile characteristics of fiber types of the rectus abdominis muscle of dogs (Canis familaris) during the reproductive cycle. 91pp. Universdade do Oeste Paulista (UNOESTE - Presidente Prudente - SP - MSc. Dissertation), 2003.

Dubowitz, V. \& Brooke, M. H. Muscle Biopsy: A Modern Approach. Philadelphia, Saunders, 1972. 432pp.

Dubowitz, V.; Sewry, C. A. \& Fitzsimmons, R. B. Muscle biopsies a practical approach. $2^{\text {end }}$. London, Philadelphia \& Toronto, Bailer Tidal, 1985. 720pp.

Grinton, S.; Powers, S. K.; Lawlwer, L.; Criswell, D.; Dodd, S. \& Edwards, W. Endurance training-induced increases in expiratory muscle oxidative capacity. Med. Science., 24(5):551-5, 1992.

Hijikata, T.; Wakiaka, H. \& Yohro, T. Architectural design, fiber-type composition and enervation of the rat rectus abdominis muscle. Anat. Rec., 234:500-12, 1992.

Ito, J. Fyber type composition of abdominal muscles in Japanese macaques (Macaca fuscata). Okajimas Folia Anat. Jpn., 74(6):199-205, 1998.

Korhonen, M. T.; Cristea, A.; Alén, M.; Hakkinen, K.; Sipila, 
S.; Mero, A.; Viitasalo, J. T.; Larsson, L. \& Suominen, $\mathrm{H}$. Aging, muscle fiber type, and contractile function in sprint-trained athletes. J. Apll. Physiol., 101:906-17, 2006.

McMannus, J. F. A. \& Mowry, R. W. Histochemical studies on developing mast cells. Anat. Rec., :265-9, 1964.

Mcardle, W. D. O sistema pulmonar e exercício. Fundamentos de fisiologia do exercício. 2. ed. Rio de Janeiro, Guanabara Koogan, 2002. 236pp.

Mitchell, T.W.; Turner, N.; Hubert, A. J.; Else, P. L.; Hawlwy, J. A.; Lee, J. S.; Bruce, C. R. \& Blanksby, S. J. Exercise alters the profile phospholipids molecular species in rat skeletal muscle. J. Appl. Physiol., 97(5):1823-9, 2004.

Mole, P. \& Stern, T. C. Effects of pre and perinatal malnutrition on muscle fibers from fast and slow rat muscles. Resp. Exp. Med., 173:35-40, 1982.

Moore, A. J.; Stubbings, E. B. S.; Dusmet, M.; Goldstraw, Polcher, R.; Moxham, J.; Polkey, M. I. \& Ferenczi, M. A. Passive properties of the diaphragm in COPD. J. Appl. Physiol., 101:1400-5, 2006.

Pyshkin, A. \& Baulin, L. Sodium thiopental an anesthesic for wild animals. Veterinary, 46(4):75-6, 1969.

Petter, J. B.; Barnard, R. J.; Edgerton, V. R.; Gillespiie, C. A. \& Stempel, K. E. Metabolic profiles of three fiber types of skeletal muscle in guinea pigs and rabbits. Biochemistry, 11:2627-37, 1972.

Powers, S. K.; Coombes, J. \& Demirel, H. Exercise traininginduced changes in respiratory muscles. Sports Med., 24(2):121-31, 1997.

Powers, S. K.; Criswell, D.; Lieu, F. K. et al. Exerciseinduced cellular alterations in the diaphragm. Am. J. Physiol., 263:1093-8, 1992.

Saad, P. B.; Guimarães, A.; Pai Dal, V. \& Kroll, L. B. Análise histológica e histoquímica das fibras dos músculos reto do abdome e intercostal paraesternal de ratos submetidos ao exercício de natação. Rev. Bras. Med. Esporte., 8(4):1$7,2002$.

Shell, W. A. Respiratory muscle training in healthy individuals: Physiological rationale and implications for exercise performance. J. Appl. Physiol., 32(9):567-8, 2002.
Simoneau, J.; Lortice, G.; Boulay, M. R.; Marcotte, M.; Thibauld, M. C. \& Bouchard, C. C. Human skeletal muscle fiber alteration with high-intensity intermittent training. Eur. J. Appl. Physiol., 54:250-3, 1985.

Song, W.; Kwak, H. B. \& Lawlwer, J. M. Exercise training attenuates age-induced changes in apoptotic signaling in rat skeletal muscle. Antioxid. Redox Signal., 8(3-4): 517-28, 2006.

Tamaki, N. Effect of endurance training on muscle fiber type composition and capillary supply in rat diaphragm. Eur. J. Appl. Physiol., 56(2):127-31, 1987.

Trappe, S.; Costill, D. \& Thomaz, R. Effect of swim, taper on whole muscle and single muscle fiber contractile properties. Human Performance Laboratory, Ball State University, Muncie, In 47306. Med \& Scienc in Sports \& Exerc., 32(12): 48-56, 2000.

Uribe, J.; Stump, C.; Tipton, C. \& Fregosi, R. F. Influence of exercise training on the oxidative capacity of rat abdominal muscles. Resp. Physiol., 88:171-80, 1992.

Woolstenhulme, M. T.; Conlee, R. K.; Drummond, M. J.; Stites, A. W. \& Parcell, A. C. Temporal response of desmin and distrophin proteins to progressive resistance exercise in human skeletal muscle. J. Appl. Physiol., 100(6):1876-82, 2006.

\section{Correspondence to}

Dra. Maria José Alvarez Rosa

Department of Physiotherapy - UNOESTE

Rua José Bongiovani, 700

CEP 19050-680

Presidente Prudente, SP

BRASIL

Tel.: +55 0182291055

Fax: +55 0182291013 .

Email:mjrosa@unoeste.br

Received: 26-03-2007

Accepted: 28-06-2007 